Finanse, Rynki Finansowe, Ubezpieczenia nr 6/2017 (90)

DOI: $10.18276 /$ frfu.2017.90-04

s. $51-65$

\title{
Heuristic. Psychological Aspects of Decision-Making on Capital Market - Literature Review
}

\author{
Magdalena Mikołajek-Gocejna*
}

\begin{abstract}
Purpose - the aim of this paper is to review the impact of heuristics bias decision-making on capital market. Heuristics are efficient cognitive processes that ignore part of information. In classical view, heuristic decisions save effort, but imply greater errors then "rational" decisions, defined by logic and statistical model. It clearly emerges that in real life people do not always make rational decisions based on established preferences and complete information. In many ways their behavior thus contradicts the homo oeconomicus model. These psychologically driven inadequacies also occur with investment decisions.

Design/methodology/approach - literature review.

Findings - much of the behaviour observed is caused through people trying to cope with the complexity of the world around them by approximating, because collating and evaluating all the factors of relevance to a decision overtaxes their mental processing capacity

Originality/value - article can be base to formulating new concept of rationality or new concept of homo oeconomicus (Mikołajek-Gocejna, 2017).
\end{abstract}

Keywords: market efficiency, heuristics, homo oeconomicus, motivational and recognition biases

\section{Introduction}

The classical finance assumes that capital markets are efficient, investor are rational and it is not possible to outperform the market over the long term. Rational man is assumed to be economical, knowledgeable, and skillful in calculating the probabilities of each alternative, and then to choose the best alternative that maxims his utility for the lowest cost (Simon, 1995). Classical finance has a cornerstone - the Efficient Market Hypothesis (EMH) which assumes that prices of stock and other financial instruments are valuated correctly and they always reflect all the information available (Sharpe, 1995, p. 105-107). So, the capital market is efficient information-wise if it guarantees all market participants immediate access to information (Gabryś, 2006, p. 477). The market efficiency theory has been developed by Eugene Fama, who in his firstpapers on the subject defined it as a market that quickly and unequivocally adjusts to new information (Fama, 1970). The contemporary and more mature definition states that:

\footnotetext{
" prof. nadzw. dr hab. Magdalena Mikołajek-Gocejna, Szkoła Główna Handlowa w Warszawie, Instytut Zarządzania Wartością, 02-544 Warszawa, ul. Madalińskiego 31/33, e-mail: magdalena.mikgoc@gmail.com.
} 
An 'efficient' market is defined as a market where there are large numbers of rational, profit-maximizers actively competing, with each trying to predict future market values of individual securities, and where important current information is almost freely available to all participants. In an efficient market, competition among the many intelligent participants leads to a situation where, at any point in time, actual prices of individual securities already reflect the effects of information based both on events that have already occurred and on events which, as of now, the market expects to take place in the future (Fama, 1995, p. 76).

The efficient market hypothesis exists in three variants that assume different types of information, which are reflected in securities prices (Fama, 1991):

4. Weak form efficiency (WFE) assumes that prices reflect all past information. WFE implies that it is impossible to forecast securities prices drawing from historical prices, i.e. from technical analysis which uses charts of past stock quotes (Peters, 1999, p. 19). This implies that investors who use historical data cannot simply beat or predict the market.

5. Semi-strong form efficiency (SSFE) assumes that securities prices reflect all publicly available information, i.e. the information that can be read out from time series and the information included in current or periodical reports, companies' financial reports and in other sources that can affect stock prices. This implies that investors who use historical data and publicity released information cannot achieve superior return. ${ }^{1}$

6. Strong form efficiency (SFE) assumes that the market is efficient when the price of asecurity reflects all the publicly available information, all the publicly unavailable information, and confidential information. Thus, the future developments in prices cannot before casted even if one holds information unavailable to others. In such

1 The most interesting work in the field of semi-strong efficiency is concerned with: 1 . The market's reaction to a new offering. This has been verified by Kraus and Stoll (1972); the results revealed that the price quickly returns to the previous value which confirms the market's efficiency. 2 . The effect of the announcement of merger, which has been studied by Patell and Wolfson (1984). The price adjustment followed the announcement by a dozen of minutes, which confirmed semi-strong efficiency. 3. The impact on the rate of dividend on the possibil-ity to project returns, which has been studied by Fama and French (1988) and Campbell and Shiller (1988). They have demonstrated that $40 \%$ of future rates volatility can be accounted for thanks to observations of the initial level of the indicator. 4. Malkiel (2003) has linked the effect of dividend yield with the level of interest rates and with the adjustment of securities valuation to economic circumstance; moreover he observed that starting from the mid $80 \mathrm{~s}$ the effect of dividend yield started to die out. 5. The effect of the split on a security's price linked to an increases dividend has been studied by Fama, French, Jensen and Roll (1969). The results of their study confirmed the semi-strong efficiency hypothesis. 6. The influence of the P/E ratio on the rate of return has been analysed by Basu (1977), who has proven that shares with a lower $\mathrm{P} / \mathrm{E}$ have a higher rate of return than shares with a high $\mathrm{P} / \mathrm{E}$; Banz (1981) has contributed an observation that the return is even higher in the case of companies with lower capitalisation. Both authors were inclined to refute the SSFE hypothesis. 7. Kester (1990) in his research records a small-size firm effect; he argues that they offer more opportunities for achieving abnormal returns than in the case of firms with high capitalisation. 8. The announcement of unexpected results has been analysed by Ball (1978). In his analysis, he obtained a rate of return significantly different from the average, which constituted an argument against efficiency. The author, however, attributed the lack of efficiency to CAPM which he used to compare risk. Watts (1978) and Rendleman, Jones and Latane (1982) have received similar results. 9. Strategies based on the effects of $\mathrm{P} / \mathrm{E}$, capitalisation and $\mathrm{P} / \mathrm{BV}$ have been verified in the context of the Polish capital market from September 1994 to September 2000 (Czekaj, Woś, Żarnowski, 2001). The study argued in favour of the efficiency and the increase of return was deemed statistically insignificant. 
a situation, all analyses of information are pointless. This implies that investors who trade based on past, public and insider information will be not able to achieve aboveaverage risk adjusted return (Reilly, Brown, 2011).

Efficient market hypothesis highlight the fact that absolute rationality of the capital market characterized by the fact that all investors are rational it is a statement of fact and must generally accepted.

But if we compared the model homo oeconomicus with the results of psychological experiments, it is clearly emerges that in real life people do not always make rational decisions based on complete information. They are not rational utility-optymalization machines. In many ways their bahavior thus contradicts the rational man model.

The same applies to investors. Behvioral finance provides a different perspective to understand decision-making process, suggesting that investment decisions is influenced in large portion by psychological and emotional factors, such as: fear, panic, anxiety, envy, euphoria, greed, satisfaction, ambition or vanity. Behavioral finance holds that investors tend to fall into predictable patterns of critical behavior, they made the same mistakes frequently. Growing complexity and uncertainty of decision-making process has caused that investor to greater extend rely on heuristics. This could lead to bias or less-than-optimal decisions. But simple heuristics can be more accurate than complex procedures is one of the major discoveries of the last decades (Gigerenzer, Hertwig, Pachur, 2011).

\section{Heuristics an Prospect Theory}

The term heuristic is of Greek origin, meaning "serving to find out or discover". The mathematician George Polya distinguished heuristics from analytic methods; for instance, heuristics are indispensable for finding a proof, whereas analysis is required to check a proof's validity. In psychology, heuristics can be defined as "a mental shortcut that allow people to solve problems and make quick judgments" or "a very simple procedure that helps find adequate, though often imperfect, answer to difficult questions" (Forbes, Hudson, Skerratt, Soufian, 2015). Similarly, but in a more positive way, Gigerenzer and Gaissmaier (2011, p. 454) offered the following definition: "A heuristic is a strategy that ignores part of the information, which the goal of making decisions more quickly, frugally and/or accurately than more complex methods". Authors argue that the reason why investors make such intensive use of simple rules for financial decision-making is simply, because they work. Fast and frugal reasoning, which focuses on a few cue variables, happens for two main reasons (Forbes et al., 2015):

1. People are boundedly rational, they want to make the right choice, but making some choice is even more important.

2. Many decisions are considered under condition of uncertainty not risk, and we are often unable to attach possibilities to specific situations. 
However, heuristics will probably not apply when attempting to make decisions in dynamic and complex environment like the capital market. In such circumstances they can lead to cognitive biases in decision making (Tversky, Kahneman, 1974). Authors state that "cognitive bias is a common tendency to acquire and process information by filtering it through one's own likes, dislikes, and experiences regarding the reality”. Such bias can lead to a perceptual distortion, inaccurate judgment, or illogical interpretation of financial information. Therefore, under the risk, the decisions is usually made based on person's belief and preference instead of facts.

In 1979, psychologists Daniel Kahneman and Amos Tversky put forward a hypothesis describing real-life behaviour of people under risk, i.e. the prospect theory, which took into account empirical data concerning decision-making under uncertainty (Tversky, Kahneman 1982, p. 163-178).

The first formal attempt at decision-making under risk, however, was made much earlier by Blaise Pascal, who recommended to maximise expected value, defined as the sum of products of the probabilities of occurrence of subsequent events multiplied by the value assigned to subsequent events (Zielonka, 2011). In 1783, Daniel Bernoulli proposed a new model of decision-making under risk where he replaced expected value with expected utility. Heassumed that the curve of utility will be concave, because then the increase of satisfaction from greater wealth gets smaller and smaller (Zielonka, 2011). Bernoulli did not define a function for losses, which Kahneman and Tversky made up for in their prospect theory. It is the most important theory regarding the motivations of investors and it comprises of two parts: the first one concerns utility, the other - probability.

Kahneman and Tversky preferred the term "value" to "utility". They meticulously analysed the shape of the functions of potential losses and potential gains. The value function in losses is concave and relatively steep, while the value function in gains is convex and less steep. These features are very important in the context of attitudes in face of risk. If we lose $\$ 500$, we will feel the loss more strongly than we feel the joy from gaining $\$ 500$.

Moreover, the prospect theory assumes that investors' preferences and expectations will also depend on how the problem is formulated. If the reference point is chosen in such a way that the result of the decision will be perceived as gain, the investor will be risk averse. Otherwise they will be risk seeking (Zielonka, 2003).

The first part of the prospect theory also implies that the subjective and perceptible value of an investor's wealth is related to changes both in gains, and in losses. It means that subsequent gains bring smaller increase in value, so do losses.

The second part of the theory concerns the way in which investors estimate probability of particular events. Instead of the probability function, Kahneman and Tversky introduced the weighting function, because they argued investors tend to underestimate medium and large probabilities, but they overestimate low probabilities (Zielonka, 2003). 


\subsection{Motivational biases}

Among investors' motivational biases the following can be also enumerated:

- Mental accounting (Zielonka, 2011), i.e. irrational dividing of different types of investment and considering potential gains or losses separately for each. Investors are more prone to consume the return on stock if it comes from a dividend rather than if it results from a price increase on the capital market. It means investors treat differently their profits from dividends and from price growth.

- Endowment effect, i.e. a different perception of securities an investor already owns. Such assets are usually ascribed more value because investors treat them with preference (Samuelson, Zeckhauser, 1988).

- Attachment effect and status quo effect are very similar biases in which the will to keep the existing state of affairs prevails. It turns out that if an investor holds shares of a certain company for a long time or has an emotional bond with it, they will be averse to sell the shares, sometimes regardless of circumstances.

- Disposition effect, i.e. a tendency to sell too soon shares whose price has increased and to keep assets whose value has dropped. Odean (1998) analysed ca. 10 thousand individual accounts and concluded that individual investors are prone to this bias they clearly tend to realise their earnings and they are averse to close their position in losing stock, although it is irrational from the point of view of taxation.

Table 1

Table Summary of articles on the disposition effect

\begin{tabular}{|c|c|c|}
\hline Article & Dataset & Main Finding \\
\hline 1 & 2 & 3 \\
\hline Barber et al. (2007) & $\begin{array}{l}\text { Taiwan Stock Exchage } \\
\text { 1995-1999 }\end{array}$ & $\begin{array}{l}\text { The disposition effect is present for individual } \\
\text { and institutional investors (mutual funds, corporations, } \\
\text { dealers, and foreigners). Individuals have the strongest } \\
\text { disposition effect }\end{array}$ \\
\hline Brown et al. (2006) & $\begin{array}{l}\text { Australian Stock } \\
\text { Exchange 1995-2000 }\end{array}$ & $\begin{array}{l}\text { The disposition effect is present for individual and } \\
\text { institutional investors in the Australian IPO market, } \\
\text { though traders making large trades are less prone } \\
\text { to the disposition effect }\end{array}$ \\
\hline $\begin{array}{l}\text { Calvet, Campbell, } \\
\text { and Sodini (2009) }\end{array}$ & $\begin{array}{l}\text { Statistics Sweden } \\
1992-2002\end{array}$ & $\begin{array}{l}\text { Provides a comprehensive analysis of motivation } \\
\text { for portfolio rebalancing. Less sophisticated households } \\
\text { are more likely to sell winners and hold loser }\end{array}$ \\
\hline $\begin{array}{l}\text { Feng and Seasholes } \\
(2005)\end{array}$ & $\begin{array}{l}\text { Chinese Broker } \\
\text { 2005-2006 }\end{array}$ & $\begin{array}{l}\text { Trading experience and investor sophistication } \\
\text { ameliorate the disposition effect }\end{array}$ \\
\hline Dhar and Zhu (2006) & $\begin{array}{l}\text { US Discount Broker } \\
\text { 1991-1996 }\end{array}$ & $\begin{array}{l}\text { Among individual investors, the disposition effect is } \\
\text { weaker among the wealthy and those employed } \\
\text { as professionals }\end{array}$ \\
\hline
\end{tabular}




\begin{tabular}{|c|c|c|}
\hline 1 & 2 & 3 \\
\hline Frazzini (2006) & $\begin{array}{l}\text { Thomson Financial } \\
\text { CDA/ Spectrum Mutual } \\
\text { Fund }\end{array}$ & $\begin{array}{l}\text { Mutual funds sell equities held for a gain at a higher rate } \\
\text { than those held for a loss, and this tendency is stronger } \\
\text { following years of poor fund performance }\end{array}$ \\
\hline $\begin{array}{l}\text { Grinblatt and } \\
\text { Keloharju (2001) }\end{array}$ & $\begin{array}{l}\text { Finland Stock Exchange } \\
\text { 1995-1996 }\end{array}$ & Individual investors sell winners and hold losers \\
\hline Heath et al. (1999) & $\begin{array}{l}\text { Employee Stock Options } \\
\text { at Seven US Companies } \\
1985-1994\end{array}$ & $\begin{array}{l}\text { Employee stock options are more likely to be exercised } \\
\text { when the stock is trading above its prior-year high }\end{array}$ \\
\hline Odean (1998) & $\begin{array}{l}\text { US Discount Broker } \\
1987-1993\end{array}$ & Individual investors sell winners and hold losers \\
\hline $\begin{array}{l}\text { Shapira and Veneazia } \\
(2001)\end{array}$ & Israeli Broker 1994 & $\begin{array}{l}\text { Both professionally managed accounts and self-managed } \\
\text { accounts display a disposition effect. The effect is most } \\
\text { pronounced for self-managed accounts }\end{array}$ \\
\hline $\begin{array}{l}\text { Weber and Camerer } \\
\text { (1998) }\end{array}$ & Experimental Market & $\begin{array}{l}\text { Subjects participating in an experimental stock market } \\
\text { are more likely to sell winners rather than losers. } \\
\text { The disposition effect is mitigated when investors } \\
\text { are forced to sell all positions and then repurchase }\end{array}$ \\
\hline
\end{tabular}

Source: own.

- Myopic loss aversion describes a situation when an investor feel uncomfortable with temporary decline in stock prices (Zielonka, 2011), even if in the case of long-term investment. As a result, investors prefer low-risk financial instruments, for example treasury bonds, even if in the long-term they yield much smaller return than more risky instruments.

- Cognitive dissonance is a state of psychological discomfort which appears when an individual has to deal with two contradictory cognitive elements, for example ideas or opinions (Festinger, 1957). The dissonance causes motivational stress and triggers action aimed at reducing or mitigating the stress. When traders on the capital market choose a company, they believe their investment will be successful. If the company fails, they try to focus only on positive information about the company, in order to reduce the tension caused by the dissonance between the choice the investor has made and unsatisfactory return from investment

\subsection{Cognitive biases}

Investors' decisions are not only burdened with motivational biases, but also with cognitive biases, i.e. the tendency to quickly form opinions that are supposed to solve complex problems. In the perspective of this book, the most important cognitive biases are (Zielonka, 2003, 2011):

- Overconfidence - investors hold an unfounded opinion that their judgment is correct and they tend to overestimate their abilities. In guise of empirical evidence, the study 
carried out by Barber and Odean can be evoked. Following an analysis of individual investors' accounts, they concluded that the more confident investors feel about their know-how and skill, the more they trade (Barber, Odean, 2000). A study conducted on the Warsaw Stock Exchange -analysts were asked to forecast the WIG index for the six following months -confirmed that analysts are overconfident as to their competence, because only one third of forecasts were accurate (Zaleśkiewicz, 2011). Several papers have developed theoretical models based on the observation that investors are overconfident (Benos, 1998; Caballe, Sakovics, 2003; Daniel, Hirshleifer, Subrahmanyam, 2001; Gervais, Odean, 2001; Hong, Scheinkman, Xiong, 2006; Kyle, Wang, 1997; Odean, 1998; Peng, Xiong, 2006; Scheinkman, Xiong, 2003; Wang, 2001). Generally, these models assume investors suffer from the miscalibration type of overconfidence. For example, one can extend the classic models of Kyle (1985), Grossman and Stiglitz (1980), or Diamond and Varecchia (1981) by assuming some investors are miscalibrated (or overconfident) about the precision of their information (see Odean, 1999). In these three settings, the overconfidence models generally predict that investors will trade too much and to their detriment

- Illusion of control, i.e. an investor's subjective belief that they are able to control the course of events, which in fact, happen independently of the investor. Presson and Benazzi (1996) defined factors that determine the feeling of control on the financial market. Firstly, the choice - if an investor chooses their stock or investment portfolio on their own, they will strengthen the belief they can influence the course of events, in contrast to a situation when he would be randomly ascribed some stock. Secondly, if an investor makes a good decision a couple of times in a row, he usually feels he is able to control the course of events, even if the decision just coincidentally happened to be right. The authors dub such phenomenon an outcome sequence. Another factor strengthening the illusion of control is familiarity; stock market investments are popular, so even an unseasoned investor can be under the impression that he is able to make good investment decisions. The amount of incoming information is also important; it does not always improve the investor's knowledge but it definitely increases the illusion of control. The investor's involvement in managing the investment account also contributes to this illusion. The greater the independence, the stronger the illusion of control over investment.

- Hindsight bias. Predicting the tendencies of financial markets is extremely difficult - if not impossible - since contemporary market mechanisms are very complex. However, when an event which was hardly probable occurs, investors claim that it had been possible to predict. Such bias makes it harder for investors to see the mistakes they made in their forecasts.

- Excessive optimism, which occurs when investors believe the course of events will be favourable to them. It usually happens in the time of bull market. Moreover, excessive optimism can make traders overestimate the probability of occurrence of rare desired events and underestimate the probability of undesired events, which in consequence can lead do excessively risky behaviour. 
- Anchoring effect means that stock price can depend on a certain initial value, which is used as a reference point. On financial markets, where there are no absolute values and we constantly need to refer to relative values, anchoring plays an important role. As an illustration we can evoke the tendency to treat as a point of reference the WIG 20000 index from the period of bear market on the Warsaw Stock Exchange in the early 1990s. Anchoring effect can be often observed upon the first public issue of shares. At such a moment, the valuation of a company is to a certain extent subjective, but if a high stock price is anchored, traders will perceive each opportunity to buy shares at a lower price as an attractive investment. On the Polish capital market, Buczek and Pietrzak (2004, p. 14)studied anchoring effect in a group of stock analysts from 1999 through 2003. The authors analysed recommendations concerning IT companies. In this period, stock quotes in the new technologies industry fluctuated considerably. Buczek and Pietrzak's analysis revealed that analysts adjusted the valuation of particular companies to their market value which worked as an anchor.

- Availability heuristic is a mental shortcut which makes investors have more confidence in companies which are familiar to them, i.e. in things they have see nor heard about before. E. Stephen illustrated how availability heuristic worked in a study of German investors (Stephan, 1999; quoted in: Zielonka, 2011, p. 61). Hedrafted a list of companies with easily recognizable names and a list of little known companies. Next, all the names were read out to traders and for each name the researcher informed whether the firm generated profits or losses. It turned out that if profits were ascribed to well-known companies and the losses to little known ones, investors believed that the majority yielded profits; they memorised financial results of popular companies better and the names they were familiar, which determined the final impression

- Representativeness heuristic on the capital market denotes, generally speaking, investors' tendency to foresee a continuation of existing trends, if they are able to find plausible cause and effect for such an event (for example they might forecast a rising trend for a company that announces positive financial results). If investors are unable to find a simple explanation, they treat a given series of events as are sult of chance to a large degree and they are not inclined to make non-regressive predictions (Andreassen, 1987).

- Investor sentiment, or over-reaction and under-reaction to information. Over reaction occurs when traders react excessively to a series of information about a given company, for example to a series of positive pieces of information. If an investor is observing a company which generates increasingly high income and operates in an interesting market segment, it induces the investor to forecast arising trend, which can push the stock price up. Only in later years the quotes will start to decrease and reach a level adequate to the data announced previously. An analogous phenomenon can occur in the case of a company which announces bad financial results. Underreaction consists in an insufficient reaction which mainly follows an announcement of a surprising piece of fundamental information, such as a sudden decrease 
in a company's profits after a series of increases. In literature, various definitions and classifications of investor sentiment exist. For instance, Baker and Wurgler (2007) revealed through their comparison of stock quotes that changes in investors' sentiment affect considerably, noticeably and repeatedly the shares of a given company and the entire capital market. This effect was particularly pronounced in the case of companies whose stock quotes were unstable and which were difficult to valuate in an objective manner. There exist several theoretical models which demonstrate the influence investor sentiment has on stock prices and the valuation of assets (Barberis, Shleifer, Vishy, 1998; Welch, Qiu, 2004; Shefrin, 2007; Baker, Wurgle, 2007; Daniel, Hirshleifer, Subrahmanyam, 2001) but there are few studies which attempt to measure investor sentiment (Lee, Shleifer, Thaler, 1998; Neal, Wheatley, 1998; Brown, Cliff, 2004). Among the latter, two types of measurement can be distinguished: direct and indirect. Direct measuring uses surveys, and indirect measuring involves widely available information and its correlation with investor sentiment. Other papers focus on the influence of investor sentiment on stock returns (Solt, Statman, 1989; Brown, Cliff, 2005; Baker, Wurgler, 2006). Lee, Jiang and Indro's research (2002) suggest that investor sentiment correlated with changes in stock quotes automatically translate into return on investment. What is more, a positive change in sentiment leads investors to evaluate the market as more stable and to expect a greater return. A negative change makes the market seem unstable and results and in smaller expectations of earnings. The issue of investor sentiment is of major importance in contemporary economy, since - as Zouaoui, Nouyrigat and Beer's study reveals (2010) - the attitude of investors can help to forecast crises. Although researchers often point out to change in (Barberis, Shleifer, Vishy, 1998; Welch, Qiu, 2004; Shefrin, 2007; Baker, Wurgler, 2007; Daniel, Hirshleifer, Subrahmanyam, 2001). Sentiment as determining factor in capital market crises (De Long, Shleifer 1990; Shiller, 2000), it is rarely analysed.

- Affect heuristic is a mental shortcut in which current emotions guide the judgment of events. It may for example lead to investors' believing that stock of reputable, well-known companies constitute a good investment and can yield a high risk-free return. It seems that the affect heuristic can also be present when traders forecast positive results for companies who initiate social responsibility actions.

The motivational biases and cognitive tendencies of investors described above can help to explain investors' behaviour. We should also assume that there exists a relationship between the psychological mindset of investors and the behaviour of financial markets. Moreover, biological factors, next to fundamental factors, play a significant role in forming traders' expectations and, as a consequence, stock prices on the capital market. 


\section{Heuristic and stock buying decisions}

Individual investor purchase stock directly for themselves to benefit from the growth of stock market or from dividends. It is certainly that it is not possible to separate investors' personality and the decision they made. A large body of empirical research indicates that real individual investors behave differently from investors in these models. Many individual investors hold under-diversified portfolios. Many apparently uninformed investors trade actively, speculatively, and to their detriment. Real investors are influenced by where they live and work. These behaviors lead to an investment portfolio far from the market portfolio proscribed by the CAPM and arguably expose investors to unnecessarily high levels of idiosyncratic riskThus, it cannot be ignored the importance of understanding the individual behavior of investor. Investment decision on capital market, consist of three dimensions: buy, sell and hold, do not focus strictly on financial theory. Buying decision are important for two reason. Barber and Odean (Barber, Odean, 2013) claimed that investors are net buyers and measuring stock buying decisions can provide a more accurate response compared to measuring a general decision-making dimension. Authors also stated, that in a long time individual buying decision can move stock prices away from the fundamental value, so they can be influential on the market. We must remember that during decision-making process investors face the pressure of time, risk or uncertainty together with the complexity of the investment environment. Such situation leads to rely on mentioned above heuristics, which can cause a less-then-optimal and costly buying decisions, that will negatively effect the portfolio return (Baber, Odean 2013). If we additional assume the herding behavior of individual investors, that their decisions create mispricing in stocks (Reitz 2005) and reducing market efficiency, which can lead to market bubble

\section{Summary}

The presence of regularly occurring anomalies in conventional economic theory was a big contributor to the formation of behavioural finance. These so-called anomalies, and their continued existence, directly violate modern financial and economic theories, which assume rational and logical behaviour. Normal humans are imperfect and information requirements are for some financial models egregious. Complexity of capital market causes that people use heuristics. They may help to explain why the market sometimes acts in an irrational manner, which is opposite to the model of perfectly informed markets. In such circumstances heuristics can lead to cognitive biases in decision making, where "cognitive bias is a common tendency to acquire and process information by filtering it through one's own likes, dislikes, and experiences regarding the reality." Such bias can lead to a perceptual distortion, inaccurate judgment, or illogical interpretation of financial information and mispricing on both individual and capital market level 


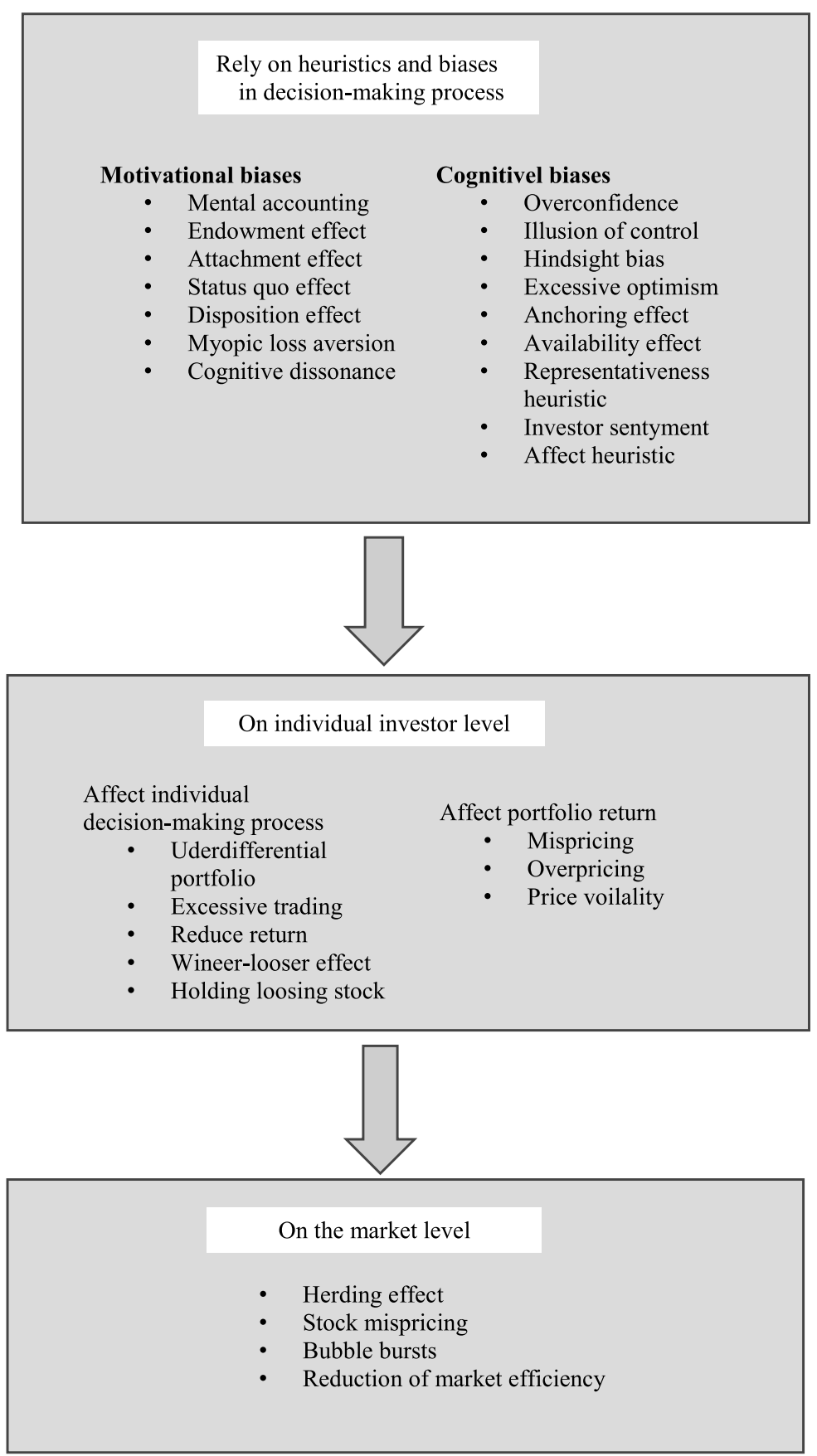

Figure 1. Rely on heuristic and biases and its consequences

Source: own. 


\section{References}

Andreassen, P.B. (1987). On the Social Psychology of the Stock Market: Aggregate Attributional Effects and the Regressiveness of Prediction. Journal of Personality and Social Psychology, 53, 90-496.

Ball, R. (1978). Anomalies in Relationships between Securities' Yields and Yield-surrogates. Journal of Financial Economics, 6 (2-3), 103-126.

Baker, M., Wurgler, J. (2006). Investor Sentiment and the Cross-section of Stock Returns. The Journal of Finance, 56 (4), 1645-1680.

Baker, M., Wurgler, J. (2007). Investor Sentiment in the Stock Market. Journal of Economic Perspectives, 21 (2), $129-152$.

Banz, R.W. (1981). The Relationship between Return and Market Value of Common Stock. Journal of Financial Economics, 9 (1), 3-1.

Barber, B., Odean, T. (2013). The behavior of Individual Investors. Handbook of the Economics of Finance, 2 , 1533-1570.

Barber, B.M., Odean, T. (2000). Trading is Hazardous to Your Wealth: The Common Stock Investment Performance of Individual Investors. Journal of Finance, 55, 773-806.

Barber, B.M., Lee, Y., Liu, Y., Odean, T. (2007). Is the Aggregate Investor Reluctant to Realize Losses? Evidence from Taiwan. European Financial Management, 13, 423-447.

Barberis, N., Shleifer, A., Vishy, R. (1998). A Model of Investor Sentiment. Journal of Financial Economics, 49, 307-343.

Basu, S. (1977). Investment Performance of Common Stocks in Relation to Their Price-Earnings Ratios: A Test of the Efficient Market Hypothesis. The Journal of Finance, 32 (3), 663-682.

Benos, A.V. (1998). Overconfident Speculators in Call Markets: Trade Patterns and Survival. Journal of Financial Markets, 1, 353-383.

Brown, G.W., Cliff, M.T. (2004). Investor Sentiment and the Near-term Stock Market. Journal of Empirical Finance, 11, 1-27.

Brown, G.W., Cliff, M.T. (2005). Investor Sentiment and Asset Valuation. Journal of Business, 78 (2), $405-440$.

Brown, P., Chappel, N., da Silva Rosa, R., Walter, T. (2006). The Reach of the Disposition Effect: Large Sample Evidence across Investors Classes. International Review of Finance, 6, 42-78.

Buczek, S., Pietrzak, M. (2004). Stadne zachowania analityków. Parkiet, 3 (6-8), 14.

Caballe, J., Sakovics, J. (2003). Speculating against an Overconfident Market. Journal of Financial Markets, 6, $199-225$.

Calvet, L.E., Campbell, J., Sodini, P. (2009). Fight or Flight? Portfolio Rebalancing by Individual Investors. Quarterly Journal of Economics, 124, 301-348.

Czekaj, J., Woś, M., Żarnowski, J. (2001). Efektywność giełdowego rynku akcji w Polsce. Z perspektywy dziesięciolecia. Warszawa: PWN.

Daniel, K.D., Hirshleifer, D., Subrahmanyam, A. (2001). Overconfidence, Arbitrage, Equilibrium, Asset Pricing. The Journal of Finance, 56 (3), 921-965.

Daniel, K., Hirshleifer, D., Teoh, S.H. (2002). Investor Psychology in Capital Markets: Evidence and Policy Implications. Journal of Monetary Economics, 49, 139-209.

De Long, J.B., Shleifer, A., Summers, L., Waldmann, R. (1990). Positive Feedback Investment Strategies and Destabilizing Rational Speculation. Journal of Finance, 45 (2), 45-50.

Dhar, R., Zhu, N. (2006). Up Close and Personal: Investor Sophistication and the Disposition Effect. Management Science, 52, 726-740.

Diamond, D.W., Verrecchia, R.E. (1981). Information Aggregation in a Noisy Rational Expectations Economy. Journal of Financial Economics, 9, 221-235.

Fama, E. (1970). Efficient Capital Markets: A Review of Theory and Empirical Work. Journal of Finance, 25 (2), 383-417.

Fama, E. (1991). Efficient Capital Markets II. Journal of Finance, 46, 1575-1617. 
Fama, E. (1995). Random Walks in Stock Market Prices. Financial Analysts Journal, 51 (1), 75-80.

Fama, E., French, K. (1988). Permanent and Temporary Component of Stock Prices. The Journal of Political Economy, 96, 246-273.

Fama, E., French, K., Jansen, M., Roll, R. (1960). The Adjustments of Stock Prices to New Information. International Economic Review, 19 (1), 1-21.

Feng, L., Seasholes, M. (2005). Do Investor Sophistication and Trading Experience Eliminate Behavioral Biases in Financial Markets? Review of Finance, 9, 305-351.

Festinger, L. (1957). A Theory of Cognitive Dissonance. Stanford: Stanford University Press.

Forbes, W., Hudson, R., Skerratt, L., Soufian, M. (2015). Which Heuristic Can Aid Financial-decision-making? International Review of Financial Analysis, June, 199-210.

Frazzini, A. (2006). The Disposition Effect and Underreaction to News. Journal of Finance, 61, 2017-2046.

Gabryś, A. (2006). Efektywność rynku kapitałowego. W: M. Panfil, A. Szablewski (ed.), Metody wyceny spótki. Perspektywa klienta i inwestora. Warszawa: Poltext.

Gervais, S., Odean, T. (2001). Learning to Be Overconfident. Review of Financial Studies, 14, 1-27.

Gigerenzer, G., Gaissmaier, W. (2011). Heuristic Decision-making. Annual Review of Psychology, 62, 451-482.

Gigerenzer, G., Hertwig, R., Pachur, T. (2011). Heuristics: The Foundations of Adaptive Behavior. New York: Oxford University Press

Grinblatt, M., Keloharju, M. (2001). What Makes Investors Trade? Journal of Finance, 56, 589-616.

Grossman, J.S., Stiglitz, J.E. (1980). On the Impossibility of Information Ally Efficient Markets. The American Economic Review, 70 (3), 393-408.

Heath, C., Huddart, S., Lang, M. (1999). Psychological Factors and Stock Option Exercise. Quarterly Journal of Economics, 114, 601-627.

Hong, H., Scheinkman, J., Xiong, W. (2006). Asset Float and Speculative Bubbles. Journal of Finance, 61, 1073-1117.

Kahneman, D., Tversky, A. (1982). Availability: A Heuristic for Judging Frequency and Probability. In: D. Kahneman, P. Slovic, A. Tversky (ed.), Judgment under Uncertainty: Heuristics and Biases. Cambridge: Cambridge University Press.

Kahneman, D., Tversky, A. (1984). Choices, Values, and Frames. American Psychologist, 39 (4), 341-350.

Kester, G.W. (1990). Market Timing with Small versus Large-firm Stocks: Potential Gains and Required Predictive Ability. Financial Analysts Journal, 46, 63-69.

Kraus, A, Stoll, H. (1972). Price Impacts of Black Trading on NYSE. Journal of Finance, 27 (3), 569-588.

Kyle, A.S. (1985). Continuous Auctions and Insider Trading. Econometrica, 53, 1315-1336.

Kyle, A.S., Wang, F.A. (1997). Speculation Duopoly with Agreement to Disagree: Can Overconfidence Survive the Market Test? Journal of Finance, 52, 2073-2090.

Lee, C.M.C., Shleifer, A., Thaler, R.H. (1998). Investor Sentiment and the Closed-end Fund Puzzle. Journal of Finance, 46, 75-109.

Lee, W.Y., Jiang C.X., Indro D.C. (2001).Stock Market Volatility, Excess Returns, and the Role of Investor Sentiment. Journal of Banking \& Finance, 26, 523-543.

Malkiel, B. (1992). Efficient Market Hypothesis. In: New Palgrave Dictionary of Money and Finance. London: Newman, MacMillan.

Neal, R., Wheatley, S.M. (1998). Do Measures of Investor Sentiment Predict returns? Journal of Finance and Quantitative Analysis, 33 (4), 591-604.

Odean, T. (1998). Volume, Volatility, Price, and Profit When all Traders are Above Average. Journal of Finance, $53,1887-1934$.

Odean, T. (1999). Do Investors Trade Too Much? American Economic Review, 89, 1279-1298.

Patell, J., Wolfson, M. (1984). The Intraday Speed of Adjustment of Stock Prices to Earnings and Dividend Announcements. Journal of Financial Economics, 13, 223-252.

Peng, L., Xiong, W. (2006). Investor Attention, Overreaction, and Category Learning. Journal of Finacial Economics, 80, 563-602.

Peters, E. (1999). Teoria chaosu a rynki kapitatowe. Warszawa: WIG-Press. 
Presson, P., Benazzi, V. (1996). Illusion of Control: A Meta-analytic Review. Journal of Social Behavior and Personality, 11, 493-510.

Radcliffe, R.C. (1982). Investments, Concept Analysis and Strategy. Glen View.

Reilly, F.K., Brown, K.C. Investment Analysis and Portfolio Management. South-Western College Pub; 10 edition (December 9, 2011).

Rendleman, R., Jones, C., Latane, H. (1982). Empirical Anomalies Based on Unexpected Earnings and the Importance of Risk Adjustments. Journal of Financial Economics, 10 (3), 269-287.

Rosses, J.B. Jr. (2003). A Nobel Prize for Asymmetric Information: The Economic of George Akerlof, Michael Spence and Joseph Stiglitz. Review of Political Economy, 15 (1), 3-21.

Samuelson, W., Zeckhauser. R. (1988). Status-quo bias in decision making. Journal of Risk and Uncertainty, 1, $7-59$.

Scheinkman, J., Xiong, W. (2003). Overconfidence and Speculative Bubbles. Journal of Political Economy, 111, $1183-1219$.

Shapira, Z., Venezia, I. (2001). Patterns of Behavior of Professionally Managed and Independent Investors. Journal of Banking and Finance, 25, 1573-1587.

Sharpe, W.F. (1995). Investments. London: Prentice Hall International.

Shefrin, H. (2007). Risk and Return in Behavioral SDF-based Asset Pricing Models. Working paper.

Shiller, R. (2000). Irrational Exuberance. Princeton University Press.

Simon, H.A. (1955). A Behavioral Model of Rational Choice. The Quarterly Journal of Economics, 69 (1), 99-118.

Skinner, D. (1994). Why Firms Voluntary Disclose Bad News. Journal of Accounting Research, 32, 38-60.

Solt, M.E., Statman, M. (1989). Good Companies, Bad Stocks. Journal of Portfolio Management, 5, 39-45.

Spence, A.M. (1973). Job Market Signaling. Quarterly Journal o Economics, 78 (3), 355-374.

Szyszka, A. (2003). Efektywność Giełdy Papierów Wartościowych w Warszawie na tle rynków dojrzałych. Poznań: Wyd. AE w Poznaniu.

Ślepaczuk, R. Anomalie rynku kapitałowego w świetle hipotezy efektywności rynku. Retrived from: http://www. efinanse.com.

Thaler, R.H. (2000). Ludzki wymiar rynku. In: Tajniki finansów. Praktyczny przewodnik po fundamentach i arkanach finansów. Warsaw: Liber.

Tobin, J. (1967). Risk Aversion and Portfolio Choice. New Haven: John Wiley \& Sons.

Tversky, A., Kahneman, D. (1974). Judgment under Uncertainty: Heuristics and Biases. American Association for the Advancement of Science, 185 (4157), 1124-1131.

Tversky, A., Kahneman, D. (1979). Prospect Theory: Analysis of Decisions Making under Risk. Econometrica, 47 (2), 263-292.

Wang, F.A. (2001). Overconfidence, Investor Sentiment, and Evolution. Journal of Financial Intermediation, 10, $138-170$.

Watts, R.L. (1978). Systematic Abnormal Returns after Quarterly Earnings Announcement. Journal of Finance, $6(2-3), 55-57$.

Weber, M., Camerer, C.F. (1998). The Disposition Effect in Securities Trading: An Experimental Analysis. Journal of Economic Behavior and Organization, 33, 167-184.

Welch, I., Qiu, I. (2004). Investor Sentiment Measures. NBER working paper.

Westerhoff, F., Reitz S. (2005). Commodity price dynamics and the nonlinear market impact of technical traders: empirical evidence for the US corn market. Physica A: Statistical Mechanics and its Applications, 349 (3-4), 641-648.

Zaleśkewicz, T. (2003). Psychologia inwestora giełdowego. Wprowadzenie do finansów behawioralnych. Gdańsk: GWP.

Zaleśkiewicz, T (2011). Psychologia ekonomiczna. Warsaw: PWN.

Zaleśkiewicz, T., Radomski, J. (2001). Investors' Risk Attitudes and Their Behaviour on the Stock Market. In: A.J. Scott (ed.), Environment and Wellbeing (p. 105-122). Proceedings of the IAREP 2001 Conference. University of Bath. 
Zielonka, P. (2003). Czym są finanse behawioralne, czyli krótkie wprowadzenie do psychologii rynków finansowych. Materiaty i Studia, 158. Warszawa: NBP.

Zielonka, P. (2011). Giełda i psychologia. Behawioralne aspekty inwestowania narybku papierów wartościowych. Warszawa: CeDeWu.

Zouaoui, M., Nouyrigat, G.J.M., Beer, F. (2010). How Does Investor Sentiment Affect Stock Market Crises? Evidence from Panel Data. Recherche, 46, 1-38.

\section{HEURYSTYKI. PSYCHOLOGICZNE ASPEKTY PODEJMOWANIA DECYZJI NA RYNKU KAPITALOWYM - PRZEGLĄD LITERATURY}

Streszczenie: $\mathrm{Cel}$ - celem artykułu jest dokonanie przeglądu wpływu heurystyk na decyzje podejmowane na rynku kapitałowym, głównie decyzje zakupu akcji. Heurystyki to efektywne procesy poznawcze ignorujące część informacji. W klasycznym wyobrażeniu decyzje bazujące na heurystykach należą do szybkich i oszczędnych decyzji, ale mogą implikować poważne odchylnia od decyzji „racjonalnych” definiowanych przez logikę i model statystyczny.

Metodologia badania - przegląd literatury.

Wynik - w prawdziwym życiu ludzie nie zawsze podejmują racjonalne decyzje oparte na ustalonych preferencjach i pełnym dostępie do informacji. Ich zachowanie jest sprzeczne z klasycznym założeniem homo oeconomicus. Wiele ludzkich zachowań podyktowanych jest próbami radzenia sobie ze złożonością świata, ponieważ zestawienie i ocena wszystkich czynników istotnych dla podjęcia decyzji przewyższa zdolności przetwarzania ludzkiego umysłu, szczególnie jeżeli chodzi o decyzje podejmowane na rynku kapitałowym. Heurystyka jest po prostu sposobem oceny wyborów w różnorodnych i zmieniających się otoczeniach decyzyjnych.

Oryginalność/wartość - artykuł może stanowić bazę dla rozważań dotyczących nowej koncepcji racjonalności bądź nowego ujęcia homo oeconomicus.

Słowa kluczowe: efektywność rynku, heurystyka, homo oeconomicus, motywacyjne i poznawcze skłonności inwestorów

\section{Cytowanie}

Mikołajek-Gocejna, M. (2017). Heuristic. Psychological Aspects of Decision-Making on Capital Market Literature Review. Finanse, Rynki Finansowe, Ubezpieczenia, 6 (90), s. 51-65. DOI: 10.18276/frfu.2017.90-04. 